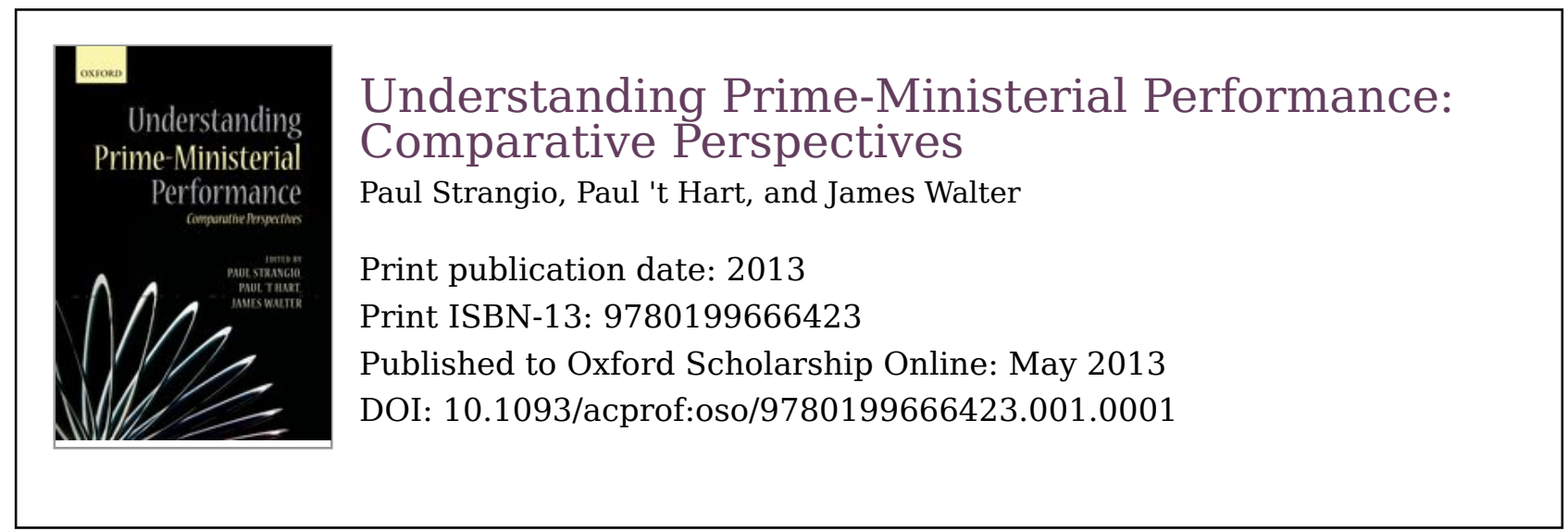

\title{
Prime Ministers and the Performance of Public Leadership
}

\author{
Paul Strangio \\ Paul't Hart \\ James Walter
}

DOI:10.1093/acprof:oso/9780199666423.003.0001

\begin{abstract}
Keywords
This chapter characterizes the role of prime ministers as public leaders: of the government, their parties, and the nation. It reviews the current state of knowledge about prime ministers, signals its limitations and sets out the research agenda of the study. It argues that understanding and evaluating how prime ministers perform their leadership function requires delving into the interplay between personal, institutional and contextual factors. It maps out the design of the collaborative and comparative research project the remainder of the book reports on.
\end{abstract}

\footnotetext{
Keywords: prime minister(s), public leadership, leadership performance, political parties, cabinet, executive government
}

\section{Prime Ministers as Public Leaders}

'From the moment the mantle is on your shoulders as prime minister, you understand that the scale, importance and complexity are completely different... You inhabit a new dimension altogether'. That is how Tony Blair remembers the overwhelming sense of expectation and responsibility that swept over him when he led British Labour into office in May 1997. He also recalls that as he breathed in the electoral triumph it dawned on him that he was fundamentally 'alone' in meeting those expectations and discharging those responsibilities (Blair 2010, 11). Prime ministers are potentially pivotal players in the politics and governments of parliamentary democracies and the responsibilities and 
expectations that go with the office can be vast. Prime ministers are expected simultaneously to be leaders of their party, their government and their country. They hold high public office and in its exercise are expected to be custodians of its dignity. At the same time, they have to be clever and at times even ruthless political operators in order to survive and thrive in the role. The centre of gravity of their efforts lies within the national political realm; yet they must at times devote a considerable share of their energy to local, regional as well as international issues and arenas. They are accountable for just about everything that goes on in the name of the governments they lead, regardless of the fact that even the most ambitious among them can know about, let alone control, only a modest part of all business that is being transacted.

Prime ministers have exceptionally multi-faceted jobs. They are architects and agenda-setters of the governments that bear their name. They are managers of ministers, cabinet processes, backbenchers, party faithful, public servants and other advisors. They are the drivers of collective decision making at the heart of government. They are its principal public face and its chief (p.2) ambassador abroad. When adversity strikes, they are national crisis manager in chief. Switching perennially between the front stage and the back stage of politics, and between the community gathering and the international summit, they convene, mediate, broker, persuade, bargain and cajole for a living.

Prime ministers work extraordinary hours, holding countless meetings, delivering speeches and processing incessant flows of information and advice. They frequently experience strong time as well political pressures. Their public and private lives are subject to relentless (and remorseless) media scrutiny. They are expected to have a solid grasp of a bewildering variety of policy issues, but they also have continuously to read the mood of the party room, key stakeholders, the commentariat and the public at large.

As the nation's chief political executive they are expected to breathe life into its politics, public policymaking and public bureaucracies. In other words, as Blick and Jones (2010) remind us, prime ministers are first and foremost expected to exercise public leadership: animating the key functions that need to be performed in order for a polity to govern itself effectively and democratically, but which are not performed spontaneously by that polity's public institutions, organizations and routines ('t Hart and Uhr 2008, 3-10). How each prime minister chooses to exercise such leadership and how successfully they perform it depends on many factors. This volume seeks to reinvigorate the study of prime-ministerial leadership. It helps explain and evaluate how the holders of the office perform the leadership roles that are associated with it. It does so by exploring the institutional and contextual 'power chances' of contemporary Westminster prime ministers (Part I), the nature of the relationship between premiers and their parties as a critical source of leadership empowerment and constraint (Part II), and the social construction of prime ministers as leadership 
'successes' and 'failures' by means of expert rankings (Part III). To put our intended contribution into perspective, we first characterize the state of the art of relevant scholarship to date.

\section{Understanding Prime-Ministerial Leadership The Agenda}

In order to evaluate the nature of a prime minister's leadership performance, we must understand the style, skills and traits that gave them the capacity to fill the top job; the success or otherwise of their relationships with colleagues and followers; and the character displayed when they were brought down (since virtually none leave in circumstances of their own choosing). We must also understand their ties with peers and followers: the relation to their parties, their cabinet colleagues, and their appeal to electorates. But we must also (p.3) comprehend the historical context. Particular personal and stylistic qualities are efficacious in some contexts, and not in others: Churchill's pugnacity and never say die attitude made him the ideal war leader, but he was markedly less successful before the war and in the transition to peace. Institutional contexts are no less important than historical juncture. These include the evolution of executive-legislative relations, the make-up of the machinery of central government, and the norms and practices governing political-administrative relations inside the core executive. All these factors bear on the opportunities available and the constraints within which a prime minister must operate-no matter what gifts or limitations he or she displays.

Prime-ministerial leadership is therefore not just a matter of personality, style and skill. It is always co-dependent: on colleagues, on followers, on stakeholders -their favours won, their trust gained, their enmity contained, their needs fulfilled. And it is always conditional: on the historical moment, on political culture and political climate, on institutional conditions and institutional change. Contrary to Blair's election night epiphany, prime ministers do not govern alone. They may be 'at the pinnacle' or 'in the centre of the centre' of executive government, but they cannot escape the fact that governing entails working with a wide range of other players in the political system who have their own powers, responsibilities, mandates and constituencies. Aligning workable coalitions of these other players to their own cause is a pivotal challenge of prime-ministerial leadership. To analyse it in any particular instance, we must understand all of these factors. It is a challenging research agenda. Moreover, if we want to understand prime-ministerial leadership performance, we should not merely study the behaviour of prime ministers and the institutional and situational forces shaping it, but also explore the normative question of how it should be evaluated as well as the empirical question of how it actually gets evaluated contemporaneously as well as historically. 
The Field Today

We do not have to start from scratch. There is no shortage of considered writing about prime ministers. The institution of the premiership within the Westminster world - the empirical focus of this volume-has been well served by historical exposition (for an overview, see Blick and Jones 2010), comparative analysis (Weller 1985; Bennister 2012) and by elucidation of core executive functions (Rhodes and Dunleavy 1995; Smith 1999). These works provide valuable leads in understanding both the evolution and the functional character of the prime minister's office as one element within a 'differentiated polity' (Bevir and Rhodes 2008).

Moreover, across the Westminster world there are hundreds of books recounting and contemplating the personal and political lives of individual (p.4) prime ministers. They follow a familiar, most often chronological, narrative structure. Partly depending on when and by whom they are written, they vary widely in their thoroughness, neutrality, and insightfulness. Many contemporary accounts of prime ministers are written by journalists or for-hire biographers, and are timed to appear in the lead-up to elections. They are designed principally to praise or damn their subject, or in any case to sell a hard and fast story to a presumably information-hungry voting public. The post-career biographies (leaving aside autobiographies by former prime ministers, which offer no evenhanded analysis) tend to be written by academic historians. They enjoy the benefit of hindsight, as well as of greater time and usually access to a larger body of research resources and more expansive written record. On balance, they are more likely to provide interpretations of a particular prime minister's style and impact that stand the test of time.

The limitation of the conventional biography, however, is that it does little to compare and contrast its subject and the circumstances in which that prime minister governed with other holders of the office and their contexts. Also, few prime-ministerial biographies explicitly engage with the questions, propositions and debates that fascinate political scientists and leadership scholars who study executive government (exceptions include Weller 1985; Ruin 1986), though some draw systematically on psychoanalytical concepts and ideas to interpret their subject's underlying drives and needs, their leadership style, the adequacy of their performance and the sources of their (in)effectiveness as public leaders (e.g. Esberey 1980; Walter 1980; Anson 1992; Brett 1997; Abse 2003).

Rich though they can be about the individual style and career of their subjects, in and of themselves biographies provide limited insight into broader patterns of prime-ministerial leadership performance within a particular jurisdiction and its constitutional and institutional underpinnings. This is only partly remedied by collective biographies of clusters of prime ministers within a certain jurisdiction. Seldom do they touch upon the nature, stability and change of the contexts in which individual prime ministers operate. Even more rarely do they attempt to 
discern trends and discontinuities in the ways in which different office-holders interpret and perform the role (e.g., Lotz 1987; Donaldson 1999; and beyond Westminster, e.g., Baring and Schöllgen 2002; März 2002; Ruin 2007; Langguth 2009).

In contrast, contextual, individual and institutional factors at play in primeministerial role-taking, consolidation and policy-shaping are the central focus of the aforementioned longitudinal-comparative accounts of the evolution of the Westminster premiership (e.g. Pal and Taras 1988; Rhodes and Dunleavy 1995; Kavanagh and Seldon 1999; Smith 1999; Foley 2000; Hennessy 2000; Rose 2001; Walter and Strangio 2007; Blick and Jones 2010). In addition, there are a number of highly valuable cross-national comparative studies of executive leadership at the heart of government, both within and beyond Westminster countries (Feit 1978; Weller 1985, 1991, 1994; Jones 1991; King (p.5) 1994; Elgie 1995; Weller et al. 1997; Helms 2005, 2012; Poguntke and Webb 2005; Rhodes et al. 2009; Bennister 2012). A joint characteristic of all these studies is that they situate prime ministers and their leadership performance within the broader configuration of executive government and its various key offices (e.g. cabinet, the public service, political staff), executive-legislative relations, party systems, and electoral politics.

The core executive approach, implicit or explicit in many of these latter efforts, was an attempt to transcend a persistent debate in prime-ministerial studies concerning whether institutions have evolved in a way that had the potential to deliver greater power to prime ministers-a discourse that was consolidated as the 'presidentialization' thesis (Foley 2000; Heffernan 2005b; Poguntke and Webb 2005). The core executive approach has recast the terms of debate by properly insisting on attention to all the key players and institutions engaging in policy at the 'heart' of government: each agency is conceived as utilizing its resources (or as engaged in resource trading) to influence outcomes. The prime minister, despite the resources of the office, is forever enmeshed in dependency relations with cabinet colleagues, party power brokers and civil servants, and hence is just one element within this scenario. Regardless of public images of them as the spider in the web of government, prime ministers cannot simply be assumed to have a determining influence for each issue that crosses their table. Policy issues and episodes should be analysed on a case-by-case basis to ascertain who exercised leadership when and how.

For all this variegated activity, both theoretically and methodologically the field of prime-ministerial studies is still underdeveloped. If we take as the main comparator US presidential analysis, some holes in our knowledge about prime ministers loom large. For example, despite the growing stock of biographies devoted to them, there is a dearth of systematic behavioural analysis of primeministerial leadership styles, the impact of these styles on political outcomes, and the contemporary and historical assessment of prime ministers as leaders. 
More broadly, notwithstanding some pioneering calls to do so and some isolated examples of what such research might yield (Kaarbo 1997; Kaarbo and Hermann 1998; Verbeek 2003; De Landtsheer 2004; Dyson 2009), there is a need for more systematic knowledge about prime-ministerial beliefs, motives, information processing propensities, management of advisers and cabinets, and decisionmaking proclivities. Students of prime ministers, cabinet government and core executive leadership in parliamentary settings have rarely employed the various personality assessment techniques that rely on content analysis of speeches and interviews-a highly productive and competitive US cottage industry in both academic and applied research-the latter reaching all the way into the bowels of the CIA (e.g. Hermann 1980, 1984; Preston 2001; Valenty and Feldman 2001; Post 2003; Winter 2005).

(p.6) A small number of scholars have investigated the rhetorical and communicative dimensions of prime-ministerial leadership. Some have also employed forms of rhetorical analysis-from formal content analysis to more interpretive, even ethnographic methods-to link individual prime ministers' verbal stances to issues of politics and governance above and beyond the usual focus on their roles in elections and campaigning (e.g. Walter 1981; Brett 1993; McAllister 2003; Masters and 't Hart 2012). This includes their roles in promoting particular narratives of national identity, (re)defining their party's ideology, and managing crises (e.g. Gaffney 1991; Uhr 2002, 2003; Curran 2004; Helms 2008; 't Hart and Tindall 2009; Toye 2011; Boin et al. 2012). There is also growing interest in the evolution of the machinery of 'media management' that has long existed around prime ministers, but which has made a quantum leap in the era of the 'postmodern' premiership where the 'framing battles' between political adversaries have become a matter of small armies of communication professionals trying to manage news cycles on their leaders' behalf (Sanders et al. 1999; Rose 2001; Seymour-Ure 2003; Spencer 2003).

\section{The Challenges Ahead}

Further progress in the analysis of prime-ministerial leadership can be made if we find cogent ways to study the interplay between political circumstances, institutional possibilities, individual characteristics and social relations at the apex of executive government (Elgie 1995; Bennister 2012). Too often, research on prime ministers seems to hinge on only one or other of the components in this network of interdependent elements. Within Westminster systems, there is a strong tradition of descriptive biography, but all too little analysis of personality and psychology. We have increasingly sophisticated insights into the core executive, cabinet government (Blondel and Muller-Rommel 1994), the role of the inner circles ('courts') around political executives in a differentiated polity (Rhodes 2011), the ethnography of political elites (Rhodes et al. 2007), and the leadership implications of ongoing transitions of parties from mass parties to electoral professional machines and cartel operations. Yet each of these critical developments is treated discretely, when what is needed in prime-ministerial 
studies is the capacity to see how each of them relates to a prime minister at work, at a specific time, in a particular context. Elgie (1995), Hargrove and Owens (2003) and Helms (2012) have given us various flavours of this type of analysis at work. Johansson's (2009) analysis of prime-ministerial leadership in New Zealand and Bennister's (2012) comparative analysis of the leadership styles of Australian prime minister John Howard and British prime minister Tony Blair are good examples of the direction this work might take in Westminster settings.

(p.7) In short, the agenda for prime-ministerial analysis needs to be moved beyond its traditional preoccupations. This volume moves in that direction by asking three interrelated questions about the leadership performance of prime ministers in Westminster systems:

- To what extent do different office-holders acquire the power needed to 'perform' their leadership roles?

- To what extent do the parties from which prime ministers spring and which they (nominally) lead enable and constrain their performance of these public leadership roles?

- And once prime ministers leave office how do their performances get assessed over time, and what do these assessments (and the public debates about them) reveal about changing societal norms and expectations concerning prime-ministerial leadership?

Each of these questions will be the focus of one part of the volume. Taken together, they allow us to probe new ways of conceptualizing, interpreting and assessing prime-ministerial leadership performance. Importantly, this is done comparatively, particularly in Parts II and III where we present national case studies from Australia, Britain, Canada and New Zealand. We introduce each of the core themes of the volume in the sections below. Before we proceed, we should acknowledge that this volume tackles only a part of the agenda for primeministerial studies identified above. Most importantly, it does not apply the tools of personality theory and social psychology to executive leadership in parliamentary systems. This limits the depth at which we examine the 'person' dimension among the constellation of factors (personal, institutional and situational) that we have argued are pivotal in shaping prime-ministerial performance (yet, see Walter, Chapter 2). Nor does it advance the nascent trend of understanding prime-ministerial leadership performance through rhetorical, dramaturgical and media analysis (Helms 2008; Toye 2011). Both these endeavours await future study.

Finally, though designed as a collaborative and comparative effort around three core questions, there is no single and shared analytical framework guiding the effort. Part III comes very close to this, in that all authors report findings of a single method of assessing prime-ministerial performance, namely expert 
ranking panels. In Part II, comparability is enhanced by the fact that there is a great deal of overlap in the way in which the four country case authors have approached the task of dissecting the dynamics of the prime minister-party relationship, but individual emphases remain apparent. The studies in Part I, finally, have no common framework at all; in fact, the very purpose of this set of papers is to showcase a variety of promising thematic and theoretical approaches to understanding the power chances of prime ministers. It is to this issue that we turn first in a series of three sections backgrounding the volume's major themes.

(p.8) Understanding Prime-Ministerial Performance: Power Chances Being prime minister is seen as the 'top job' in politics within parliamentary democracies. History provides us with numerous examples of prime ministers whose personal stamp defined their governments' agendas and decision-making processes and who were able personally to perform 'event-making' leadership. Yet for every prime-ministerial giant in the mould of Margaret Thatcher or Pierre Trudeau, history also provides counter-examples of prime ministers who were unwilling or unable to lead from the front. Their leadership style was more collegiate, their authority was more contested, and their performance considered 'weak'. Moreover, seemingly all-powerful prime ministers can come unstuck relatively quickly, suggesting that we should not make the mistake of confusing the appearance of dominance with the underlying conditional, contextual and thus potentially ephemeral nature of prime-ministerial preponderance.

The rise and even more precipitous fall of Kevin Rudd is an illuminating example. Rudd became Australia's prime minister in November 2007, just a year after being elected by a desperate Australian Labor Party (ALP)—he was the fourth leader Labor had turned to in as many terms to try and unseat the conservative government led by Liberal Party stalwart John Howard. Even before the ALP's 2007 election victory, Rudd had signalled that he would not be beholden to his party in the way he led his government. Most emphatically, he unilaterally overturned a century-old old Labor Party shibboleth by announcing that he would appoint ministers rather than their being elected by caucus. Taking office just when the global financial crisis was gathering force, Rudd styled himself as the national crisis manager, taking far-reaching recessionbusting stimulus decisions in a small kitchen cabinet of four. He monopolized the government's public communications, riding the wave of stellar personal popularity ratings. He ran his own foreign policy, and quickly became a figure of note on the world stage, which he cherished. He consolidated this centralist, top-down style of governing even when the recession threat had abated, to the growing if muted chagrin of cabinet colleagues and party elites. 
Before he had served a full term in office, however, Rudd's ascendancy began to collapse. In the election year, 2010, after the government performed an illreceived policy U-turn on climate change, major problems surfaced with the implementation of the massive stimulus package, and the prime minister picked a fight with the country's economic powerhouse-the mining industry-over the proposed imposition of a new 'super profits' tax. The government's and prime minister's opinion poll ratings nosedived. This collapse in the esteem in which his public leadership performance was held combined with growing (p.9) unease in government ranks about Rudd's reputedly authoritarian, emotionally unintelligent and disorganized backstage leadership performance. It precipitated an unravelling of his prime ministership at breath-taking speed. Having claimed control of most of the government's early successes, he was now blamed personally for its mishaps and shortcomings. Having ruled over rather than with his party, he had estranged the very people who had handed him the leadership. In June 2010, after little over two and half years as prime minister, he was deposed by a quick and brutal party-room coup. Rudd had gone from messiah to pariah, ending his term as prime minister prematurely, friendless and humiliated.

The rise and fall of Kevin Rudd epitomize the possibilities as well as the pitfalls of contemporary prime-ministerial power within Westminster parliamentary democracies. A range of contextual changes, to be explored further below, has enabled prime ministers who are so inclined to exercise a high degree of control over the government's composition and modus operandi (and see Pakulski and Körösényi 2012). When this occurs, it tends to come at the expense of the influence of their parties and the Westminster notion of collective, cabinetdriven government (Rhodes et al. 2009). This gives prime ministers considerable policy-shaping opportunities. Still, prime ministers acquire, wield and lose executive power in ways that continue to be shaped by institutional characteristics of the 'Westminster tradition'-however ambiguous and socially constructed these may be (Bevir and Rhodes 2008; Rhodes et al. 2009; Blick and Jones 2010).

This raises the question of whether the power equation that prime ministers face today differs much from that experienced by their predecessors of the immediate post-war period. Patrick Weller's First Among Equals (1985) was a pioneering analysis of prime ministers in the Westminster world, and up to this point its comparative approach has been rarely emulated (but see Bennister 2012). Weller's choice of title signified the enduring strength of collegial government and ministerial responsibility, which acted as checks on the scope and depth of prime-ministerial power. More than twenty-five years later, this way of framing the nature of prime-ministerial leadership seems to have gone out of fashion. Instead, we hear more about 'prime-ministerial government' and 'presidentialization' (the latter term relying upon a largely misleading analogy with the power of heads of government in presidential systems, see Hart 1992; 
Dowding 2012). Nonetheless, there is vigorous debate about leadership ascendancy in all liberal democratic polities (Pakulski and Körösényi 2012, 5180; McAllister 2007).

Still, some key observers of the office (Weller 1992, 2007; Blick and Jones 2010) insist that little has changed since Weller's original analysis was published: circumstances such as war might sometimes favour strong leaders; instances of 'predominance' could be found in the past that matched any contemporary outbreak of 'command and control'; the office itself remained (p.10) relatively consistent-or its scope and power varied only in a zig-zag fashion (Blick and Jones 2010, 118-26). Others see a more consistent historical trend of increasing prime-ministerial power in relation to most of the other key players in the governmental process. They identify what is often called an institutional stretch: the office of prime minister has become a more potent platform for its holders to impose their ambitions and preoccupations on everybody else. The capstone of the centralization argument in the United Kingdom hinged on extensive discussion of the Blair government (Foley 2000; Hennessy 2000, chapter 18; Allan 2003; Bennister 2007; and cf. Rhodes 2007, 2011). A typical observation emanating from an experienced commentator captures the trend:

the tight constellation of power at the top in Britain is now almost impervious to outside influence. Power has been increasingly centralized... so that Britain today is run by a small circle of key power brokers...doing various (usually secret) deals with the prime minister and his immediate inner circle of unelected advisers. The cabinet, parliament, political parties, and the various pressure groups now count for much less than they did...Opening up that closed circle is perhaps the biggest single challenge facing Britain today because it underpins all the others.

(Meacher 2010)

Similar conclusions have been reached by analysts in other Westminster jurisdictions, such as Australia (Walter and Strangio 2007; Marr 2010) and Canada (Savoie 2003). Proponents of the institutional stretch argument often refer to two mutually reinforcing phenomena that have made its occurrence possible: personalization and centralization. Both trends are said to have gained traction throughout the post-war period, with accelerating force in the last few decades.

The personalization trend stems from the increasing public focus on leadership, with prime ministers coming to be seen by the media as the embodiment of government. This is brought about by the fact that the 'social cleavage' origins of mass parties have been superseded by citizen preoccupations that no longer relate to status and encourage much more direct relations between leaders and citizens (Blondel and Thiébault 2009). In a world of 'parties without partisans' (Dalton and Wattenberg 2002), the attributes and behavior of party 
leaders become more central to the electoral contest (McAllister and Bean 2006, 2011; Aarts et al. 2011; but see King 2002). The trend is further cemented by the hollowing out of traditional party elites' abilities to act as a brake on their leaders. This has been a by-product of the international trend to 'democratize' the rules of party leader selection. Under the new regime, party leaders derive their mandates from direct elections by rank and file members, and are therefore much less dependent on their parliamentary and headquarters colleagues, although, as is shown in Chapters 2 and 8, Australia provides the exception.

(p.11) Personalization has been, almost literally, amplified by the evolution of media conventions that draw attention to leaders and the 'story' of personality conflicts rather than to policy debate. In the era of 'politainment' (Doerner 2001), media scrutiny of not just the professional but the personal lives of political elites has become much more intrusive. This has turned heads of government into celebrity-like figures, irrespective of their own efforts to court or shy away from such person-centred coverage. Whilst some herald this as an altogether beneficial if somewhat roundabout way of keeping our leaders democratically accountable (Cowen 2000), others see in it a dumbing-down of democratic leadership ideals and practices (Kane and Patapan 2012). Being in the spotlight ceaselessly has many drawbacks for a politician, but it also provides them with a powerful stage to exercise what Nye (2008) calls 'soft power', or public persuasion.

The centralization trend seen in recent decades, is one rooted in resource augmentation around the core executive, enabling prime ministers to dominate Cabinet and the civil service (Allan 2003). This refers to what Nye (2007) calls 'hard power', in this instance derived from the institutional centralization of policy co-ordination and authority in prime-ministerial departments and private office units, and the development of dense and highly centralized political advisory structures. Particularly relevant are the several waves of reforms to the civil service that have served to make the bureaucracy more responsive to incumbent governments (Walter 1986; Savoie 2003; Tiernan 2007). The consequence is said to be a greater reliance on 'inner circles'-civil servants with insider status and personal staff whose loyalty is solely to the leader.

The proponents of the institutional stretch argument do not assert that all of a sudden there are more 'power-oriented' personalities in prime-ministerial roles than in the past, or deny that some of the ambitions and actions of past premiers themselves have transformed the office. Theirs is a contextual and institutional claim instead: the interplay between changed exogenous demands and the institutional transitions effected to meet them have the consequence of allowing leaders more licence to pursue their individual proclivities. Also, rather than deterministically suggesting that all contemporary prime ministers will be more dominant than their predecessors of some decades ago, proponents of the 
institutional stretch argument claim that the combined effect of these changes is merely to enlarge the power chances of current and future office holders.

The authority necessary to lead is not conferred solely by occupancy of the office of prime minister-instead, the office is an opportunity structure for its holders. Whether this actually amounts to a particular prime minister being able to exercise considerable (hard and soft) power depends on contextual factors. These include the nature of the economic and security situation, which may dramatically affect the perceived need for forceful leadership from the (p.12) centre. But they will inevitably also depend on the personality and capabilities of the incumbent (Rhodes et al. 2009; Bennister 2012; see also Bakvis 2001; Poguntke and Webb 2005). Some prime ministers manage to exploit these opportunities and become truly dominant leaders. Other prime ministers, less willing or less adept at making the most of their power resources, exercise leadership in a more familiar and arguably more appropriately collegial fashion. They rely more on consultation, delegation and compromise.

The proponents of the institutional stretch thesis tend to share a normative concern about this development. Most consider the facts that contemporary prime ministers have more institutional clout than cabinet colleagues, legislators and bureaucrats, and can more easily claim to have a personal popular mandate, demand that we acknowledge both negative and positive effects. Observers of Thatcher and Blair-both notorious centralizers and effective personalizershave mustered plenty of evidence that prime-ministerial dominance can be a chief cause of policy fiascos such as the poll tax (Butler et al. 1994), and questionable decisions such as the British participation in the invasion of Iraq (Dyson 2006, 2007, 2009). Foley stresses the disempowering effect of such a leadership style, claiming Blair's eagerness to seize on the personalization of government had 'the effect of displacing cabinet ministers into relative obscurity and of marginalizing other political actors to the periphery of public attention' (Foley 2004: 293; and see Heffernan 2005a: 608). Walter $(2006,2008)$ and Walter and Strangio (2007) likewise point out that highly centralized, leader-centred modes of decision making are more likely to produce less well vetted and therefore more often ineffective policies (Janis 1989; 't Hart 1994). Others signal the danger of the roller coaster rides that await governments and parties overshadowed by dominant prime ministers. They reason that because a prime minister's 'bad' performances are now seen and talked about as widely as 'good' ones (Meyer 2001; Rose 2001; Hajer 2009), prime ministers who-like Rudd and before him both Blair and Gordon Brown-lose control of the public narrative about themselves and their governments, will see their 'soft power' crumble quickly and decisively, even to the extent of dragging their governments and their parties down with them. 
Given these debates, a key analytical concern is to what extent, when and how the alleged centralization of power in and around prime ministers occurs, and by which factors it is checked and counterbalanced. To address this concern, we need conceptual frameworks specifying the resources prime ministers can command, the norms and expectations with which they have to reckon, the constraints and opportunities that open up for them, the style and substance they adopt as their own-and, ultimately, the impact all of these factors have in making or breaking their performance as public leaders. Part I of this volume encompasses just such a diverse and novel series of conceptual approaches to interpreting the power chances of prime ministers.

(p.13) Understanding Prime-Ministerial Performance: The Pm-Party Relationship

Prime ministers hold their positions entirely by virtue of being leaders of their parliamentary parties. Curiously, much of the debate about the contemporary prime ministership concentrates upon their performance in parliament; their relations with cabinet, individual ministers and the civil service; their centrality (or otherwise) in the 'core executive' and their ability to personify the 'story' of their government (Blick and Jones 2010). Yet their tenure depends not only upon electoral success, but also upon their ability to maintain the confidence and support of their party (Weller 1985, chapter 2; Helms 2002). The spectacular deposition of Kevin Rudd by his party noted earlier is merely the latest object lesson: Tony Blair relinquished the role unwillingly as his party tired of his endless rivalry with Gordon Brown in 2007; Bob Hawke was challenged and defeated by his Treasurer, Paul Keating, in 1991; Margaret Thatcher was ousted in a party 'coup' in 1990. In the longer view, 'Lloyd George resigned in 1922 because the party on which he depended withdrew its support, Grey in 1834 because his party was out of control, [and] Rockingham in 1766 because his party lacked confidence in him', leading one observer to conclude, 'party is what in modern times parliament has always been about' (Langford 2006, 394).

The chapters in Part II of this volume show that different historical contexts, ideological traditions and political cultures lead to variations in how the relations between prime minister and party play out (Helms 2002). Different levels of party discipline and processes of selection and election determine whether it is more or less difficult for a party to sanction or overthrow a prime minister (Weller 1994; LeDuc 2001; Laing and 't Hart 2011). Any study of the role must take these factors into account. But a starting point is to recognize that some fundamental features are common to all jurisdictions. A broad pattern of historical and economic change-from the emergence of mass societies to globalization-has impacted upon party organization and hence upon the roles of prime ministers. The factional or cadre precursors of modern parties allowed premiers to exercise a great deal of personalized power and patronage-Robert Walpole in the eighteenth century is often taken as the exemplar (Blick and Jones 2010, 51-8). His successors in the settler societies of European expansion 
could exercise a like degree of personal influence even into the twentieth century, Australian prime minister Alfred Deakin, and Canadian prime minister William Mackenzie King being notable examples (Walter 2009). The evolution of complex modern polities, however, generated formal bureaucratic organization and a shift away from cadre leadership, from behaviour based on private interests and personal loyalty to more disciplined parties, with action based on agreed group objectives and justified in terms of public interest.

(p.14) Industrialization, the emergence of class politics and a premium on bureaucratic organization were the preconditions of the mass parties of the twentieth century. These demanded leadership that acknowledged collective goals, recognized the rights of individual members to a voice in party affairs and subscribed to organizational imperatives. In some respects, then, prime ministers were constrained to adopt and adapt their party's ideology, to listen to their followers and to respect the party platform. It sometimes seems implicitly assumed that these conventions still (or should) govern the relations between prime minister and party. This is, however, to ignore the trajectory of party change that has both come to allow more opportunity for the dominance that underlies much of the 'presidentialization' debate (Poguntke and Webb 2005; Bevir and Rhodes 2006), and makes the tightrope of leadership more precarious at the same time. As noted above, parties allow leaders more licence, but also expect more: when hopes are disappointed, reaction can be swift and ruthless.

In the post-war period mass parties (with clear programmatic ideologies and an extensive membership) evolved into catch-all parties (attempting to net a broad constituency by matching policy to public mood), and thence to electoral professional parties (relying on communications professionals and expert advisers rather than party activists) and perhaps to cartel parties (Katz and Mair 1995). In concert, the importance of mass membership, and reliance on party activists dramatically declined. As the grass roots of the major parties have thinned out, they have become less and less representative of the wider society, vulnerable to manipulation by factions, and dominated by a so-called political class (Oborne 2007). Dwindling membership and atrophying party forums have seen a migration of authority to the parliamentary leadership and the supporting professionalized party machine.

The declining salience of socio-economic position (class) in organizing voters' worldviews has been an important contributing factor to diminishing partisan alignment. The parties have responded to an increasingly heterogeneous electorate by soft-pedalling their former core beliefs, relying instead on issueoriented and personality-driven campaigns. And as the major parties forego ideological coherence, leaders have increasingly become a surrogate for party identity and ethos: they are a chief marketing weapon and source of product differentiation to be 'sold' to the electorate by the communication experts and 'spin doctors' who are now a central element of the party's professional 
machines. In contemporary elections it is leadership image rather than party symbols that dominate campaigning. Not surprisingly, then, as party allegiances erode, 'leaders have become more important cues to guide the choice of voters' (McAllister 2003, 275; Aarts et al. 2011). Leader effects on voting intentions are now demonstrable (Bean and Mughan 1989; cf. King 2002). An Australian study, extrapolating from the outlook of some of its (p.15) respondents, observed that 'the leader may be supplanting the party as the key organizer of people's political thinking' (Brett and Moran 2006, 305).

In a climate when leaders are overshadowing parties in election campaigns, it is natural that when they succeed at the ballot box (or even in opinion polls) their parliamentary subordinates are inclined to feel they owe their seats to the leader rather than to the party or its doctrines. In other words, the new dispensation encourages deference to the successful leader. Similarly, it has been recognized that the scope for leadership (and particularly prime-ministerial) preferment is being enlarged as party structures decline. The dominant parties are now capital intensive, professional, centralized and dependent on the projection of leader effectiveness. The networks of advice and support, capital generation and communication centre on the leader rather than the party at large, giving the leader a licence and impact unmatched in former party structures (Walter and Strangio 2007).

This party change has been both shaped, and undergirded, by globalization. In times of transition and rapid change, when global challenges-such as financial crises (see Chapter 2)-seem to demand immediate action, the personal capacities of those who exercise leadership become unusually significant. The overriding impression is that globalization presents limited options ('There is no alternative' was Margaret Thatcher's mantra); its challenges having a degree of complexity that confounds 'ordinary' understanding (so they remain the preserve of knowledge elites), needing urgent attention (that truncates consultation and negotiation), and demanding action 'now' (hence the premium on decisive leadership).

In short, each element of contemporary party change has augmented the significance of leadership, and hence the potential dominance of the prime minister. When individual prime ministers seize on this and perpetuate a highly centralist mode of governing, the other side of the coin may emerge: the store of resentment such leadership provokes can be fuel for internal party backlash. Blinded by years of predominance, Margaret Thatcher could not recognize her power dependence, whereas Tony Blair would find that by the time he had achieved clarity of vision, 'Labour MPs were not going to let him do just as he pleased' (Rawnsley 2010, 355-6). Further, discontent provides the ammunition for rival party 'barons' (see Bevir and Rhodes 2008) whenever an opportunity to strike is presented. Ultimately, such prime ministers, as Nigel Lawson said of Thatcher, lose the 'consent' of their cabinet colleagues (which is to say, the most 
senior members of their party) (Hennessy 2000, 434). Moreover, the professional party machine, now having a much diminished investment in ideological coherence, driven solely by 'whatever it takes' (Richardson 1994) to ensure electoral success, will show neither loyalty to principles nor sentiment if a leader appears to flag: its role in the dispatch of a prime minister can be brutal, as Rudd discovered-one provocative account likened contemporary party machines to 'street gangs' (Davis 2012).

(p.16) To accept, as George Jones $(1964,181)$ long ago suggested, that the 'prime minister is only as strong as his [sic] party, and particularly his chief colleagues, lets him be' is not to deny the significant potential that now exists for prime-ministerial leverage over executive government, as a function of the licence now granted to successful leaders by their parties, but it is to be remembered that this is always conditional (see also Blick and Jones 2010). Research into contemporary prime-ministerial roles must explore both the broad historical and economic junctures (globalization) that drive cognate transitions in most polities and most parties. It must always be undertaken within the context of party organization and party change, examining the culturally and socially specific particulars that determine how much licence a prime minister will be given. The chapters in Part II of this volume constitute attempts to do precisely that.

Evaluating Prime-Ministerial Performance: The Role of Rankings In Part III of the volume, we tackle the much-neglected issue of evaluation of prime ministers and their leadership. In his celebrated study of Britain's postWorld War Two prime ministers, Hennessy tiptoes into proposing an 'index of performance' for those leaders. He commences, though, with a caution by invoking the former Labour politician and scholar David Marquand's warning against posing as 'celestial chief justice...[our] judgements can never be more than provisional' (Hennessy 2000, 541-4). Yet judgements of prime-ministerial performance are ubiquitous: by media commentators on a rolling daily basis, by electors, and by their parliamentary colleagues. Their predecessors and successors also get into the game. In his memoirs, Tony Blair portrays Gordon Brown's premiership as a disaster-in-waiting that was 'never going to work', not least because Brown was bereft of 'political feelings' and 'emotional intelligence' (Blair 2010, 616, 655). Some twelve months before he became prime minister in a 1991 leadership coup that overthrew Bob Hawke, Paul Keating cast a more blanket but no less jaundiced judgement by musing that Australia had never been blessed with great political leadership. No one of the calibre of a Washington, Lincoln or Franklin Roosevelt had graced the Australian political stage. The man commonly regarded as the nation's best prime minister, World War II Labor leader, John Curtin, had, on Keating's estimate, been merely 'a trier' (Kelly 2009, 38-41; Ryan 1995). 
Historians and biographers are others who have generally not been slow to gauge the success and failure of national leaders. Hennessy puts aside his reservations to devise a 'crude taxonomy' against which he classifies the (p.17) post-war inhabitants of 10 Downing Street, from 'the very top flight' or 'weather makers' (Clement Attlee and Margaret Thatcher) through to Anthony Eden who 'falls into a catastrophic category of his own' (2000, 544-6). One of Australia's most eminent historians, John Hirst, delivered a verdict on the country's primeministerial stable. In a revisionist essay on Curtin, he not only agrees with Keating's iconoclastic judgement of the Labor hero ('much overrated'), but concurs that there had been 'no great Australian prime ministers'. Hirst did not bother with a taxonomy crude or otherwise in reaching this judgement, although he does assert that the traditionally applied "Templates to assess the qualities of prime ministers-achievement, longevity, administrative capacity and so on... underestimate the extraordinary' (Hirst 2010, 167). In the final analysis, it seemed that, according to Hirst, greatness in national leadership was a matter to be intuited rather than gauged according to established indices. This is a recurring dilemma. For all the score-carding of political leaders, so often it is done without recourse to the fundamental question: 'how do we define and assess leadership success?' ('t Hart 2011). In the writings about primeministerial leadership in Westminster democracies there has been a lacuna when it comes to the development of systematic normative frameworks for the purpose of leadership assessment. Leadership scholars have long assessed leadership success by correlating different leadership characteristics and styles with aggregate level outcomes such as company survival, market share or profitability, the validity of which is debatable. However, no political analyst would, to draw the analogy, hope to be taken seriously when claiming that presidential or prime-ministerial leadership effectiveness could be inferred from movements in country GDP, employment or well-being indices. These can perhaps be gauges of the quality of government in a polity, but not of the impact and quality of individual chief executives (Lijphart 1999; Rothstein 2011). Other leadership scholars have plenty to say about the causes and forms of 'bad' or 'toxic' leadership, but tend to assume that readers know badness in a leader when they see it (Kellerman 2004; Lipman-Blumen 2004). Notwithstanding the lack of solid and widely agreed upon criteria sets, leadership scholars have not hesitated from offering a bewildering array of prescriptions on how to become a 'better' leader.

As Theakston has observed in relation to the British experience yet is more widely applicable, among political scientists there has been a focus upon the broad long-term development of the office of prime minister and related institutional developments'. This diminishes the importance of prime-ministerial 'political skills and leadership styles', reducing them to 'variables of secondary significance' (Theakston 2002, 283-4). Arguably, the continuing ambiguity over the agency of individual office holders and the power that they wield in 
parliamentary democracies (O'Malley 2007) has deterred political scientists in Westminster polities from formulating leadership typologies that seek to assess performance in the office of the prime minister with the same (p.18) assiduity as their counterparts in the United States have done in relation to presidential leadership (e.g. Barber 1972; Simonton 1987; Greenstein 2000). The reluctance to develop serious normative models of executive leadership is linked to the fact that when one begins to think hard about leadership assessments it soon becomes apparent what a minefield it is. How can we agree on the appropriate criteria of evaluation? Is it enough to equate leadership success with successful political and policy outcomes (even if it were easy to quantify these)? When evaluating performance ought we to privilege durability in office (electoral popularity) or policy impacts, or perhaps integrity of conduct and respect for institutions? How can we be sure that leaders deserve the credit (or the blame) for government outcomes when the authoring and execution of decision making is dispersed? And is it not the case that the criteria we apply for evaluating performance will inevitably be a product of the prevailing values and culture, so that those assessments will themselves be transient? Moreover, is it not also true that the information we have for forming judgements will invariably be 'incomplete, contradictory and contested' ('t Hart 2011). There are no easy resolutions to any of these dilemmas.

To acknowledge that leadership assessment is inherently problematic is not, however, an alibi for avoidance. In this volume, we take up the challenge by interrogating one approach to assessing prime-ministerial performance: rankings by groups of academic experts. In particular, we look at the experience of rankings in Australia, Britain, Canada and New Zealand, surveying their history, methodologies, limitations and results. The adoption of expert rankings has been relatively slow and sparing in these countries, as it has been throughout the Westminster democracies. This is again in sharp contrast to the United States where ratings of presidents have a venerable, although far from universally honoured, lineage. The father of ranking in America was the Harvard-based historian Arthur M. Schlesinger, who in 1948 asked 55 historians to rate the US presidents and published the results in Life magazine. The poll 'excited much interest and also much controversy', and in 1962 Schlesinger was prevailed upon to repeat the exercise for the New York Times Magazine. This time the pool of experts was expanded to 75 and also included political scientists. Schlesinger's methodology was simple yet influential. He asked respondents to grade each president in one of five categories: great, near great, average, below average and failure. He also insisted that assessment was to be exclusively related to 'performance in office, omitting everything done before or after' (Schlesinger 1997, 179-80; see also Maranell 1970, 104-13; Murray and Blessing 1994, 7-8). 
Numerous criticisms were levelled at the original Schlesinger polls, but they failed to discourage imitators, with some critics embarking on their own version of presidential ratings (e.g. Bailey 1966). The proliferation of polls on presidential performance has in turn provided the foundation for (p.19) a substantial body of literature that has not only dissected their results, but has also debated the merits of rankings and the efficacy of their varying methodologies (e.g. Murray and Blessing 1994; Faber and Faber 2000; Bose and Landis 2003; Skidmore 2004; Taranto and Leo 2004; Eland 2009).

The most common objection to rankings is that it is not possible to draw a meaningful line between leaders who served in different eras and different circumstances. According to this view, rankings endeavour to compare the 'noncomparable' because 'no two incumbents were ever dealt the same hand' (Bailey 1966, 36). Also high on the list of criticisms is that these exercises favour 'activist' leaders and especially those who have served in times of war, as a sceptical President J. F. Kennedy protested to Schlesinger (Schlesinger 1997). Other critics have argued that not only is it invidious to compare leaders who operated in different situational contexts, but that it is also problematic to assess individual leaders whose performance was dichotomous, encompassing both achievement and failure. James Macgregor Burns, the presidential biographer and leadership studies specialist, asked in relation to Richard Nixon: 'How can one evaluate such an idiosyncratic president, so brilliant and so morally lacking?' (quoted in Skidmore 2001, 497).

One way around this quandary is to employ multiple yardsticks, accommodating the swings and roundabouts of performance. But there remains the dilemma of which yardsticks and whether they ought to be given equivalent weighting. The Schlesinger polls neatly sidestepped this difficulty, as have many other leadership rankings, by eschewing specific benchmarks of performance and instead allowing experts to appraise leadership success on their own terms. Arthur M. Schlesinger Jr (1997, 179-80), who followed in the footsteps of his father by conducting his own rankings exercise in the mid-1990s, explained that it was 'assumed' that the experts 'would recognize greatness-or failure-when they saw it'. Yet this opened these exercises to the accusation that they were hopelessly subjective, with the results revealing more about the value systems (and biases) of the raters than the rated.

There has been no shortage of such claims. The original Schlesinger polls were construed by one of their harshest critics, Stanford historian, Thomas A. Bailey, to be 'a Harvard-eastern elitist-Democratic plot' (Schlesinger 1997, 181). On the other hand, as Bailey himself discovered, devising elaborate criteria for assessment with the aim of injecting a greater degree of objectivity into rankings can also have its disadvantages, not least in miring respondents in excessively cumbersome questionnaires. Moreover, as Schlesinger pointed out with some glee, Bailey, having condemned his father's polling methodology, developed 43 
yardsticks for measuring presidential performance, only for the results to be 'remarkably similar' (Schlesinger 1997, 181). This, in turn, exposes the peril of attribution, that is, rankings reflecting established reputations rather than performance (Theakston and Gill 2006, 201).

(p.20) Despite such objections, expert rankings of leadership are not only alive and well in the United States, but have also been adopted to a limited extent in Westminster democracies over recent decades (e.g. Ballard and Suedfeld 1988; Abjorensen 1992; Sheppard 1998; Granatstein and Hillmer 1999; Theakston and Gill 2006). Do they have a value beyond that of a seductive intellectual parlour game? At a basic level, rankings can be useful in countries where individualcentred studies of leadership have predominated, because they compel leadership comparisons. What MacGregor Burns (quoted in Ellis and Wildavsky $1989,16)$ once lamented of much of the research on the presidency, 'We know everything about the [individual] Presidents and nothing about the Presidency', has far greater currency in reference to prime-ministerial studies, where political biography has remained a primary investigatory mode. In addition to necessitating a comparative perspective, rankings require their designers and respondents to reflect upon the qualities that are valued in national leadership. 'It matters much less', an American presidential scholar has observed, 'how we rank a president than that we deliberate about which important values we ought to use to understand our past and shape out future' (Pfiffner 2003). Similarly, another leading US political scientist has argued that rating White House occupants 'is a parlor game, but a useful one, because it illuminates some of the criteria used by scholars of the presidency as we make our judgments about presidential performance' (Pious 2003, 65). In the context of prime-ministerial studies, where neither agreed typologies nor more or less standardized psychological indicators have gained much traction, it is especially important that the criteria scholars use in their analyses are exposed to the light.

Comparing rankings over time may also show how time contingent are the values by which we assess leadership performance, as any shifts in rating are not a product of change in the leader's own record, since these are retrospective judgements. To be sure, in some cases new information may come to light through archival discoveries, as was the case with the presidency of Dwight Eisenhower whose reputation was transformed as a result of Fred Greenstein's influential revisionist study (Greenstein 1982). Yet Greenstein's success in rehabilitating Eisenhower's presidency was more than a product of archival revelations or skilful exposition. It also hinged upon a receptiveness to his argument that aggressive activism was not synonymous with success in the White House (Murray and Blessing 1994, 96; Skidmore 2001, 497). In other words, the improved reputation of Eisenhower's presidency also signalled a different way of thinking about leadership effectiveness. 
The value of leadership rankings can be further enhanced by comparing the exercises across jurisdictions, as is the objective in this volume. This can help to highlight whether there is substantial variation in the qualities of leadership that are highly esteemed in different countries or whether there is a strong element of universality. In Canada, for example, past expert rankings have (p.21) placed great stock on a prime minister's ability to manage the federation harmoniously and effectively, and to promote unity between English and French Canadians (Granatstein and Hillmer 1999; MacDonald 2003), which is just one example of an indigenous tradition of what constitutes successful leadership. Comparing rankings across jurisdictions also sheds light on the extent to which leadership achievement-and perceptions of this achievement-are determined by the external environment in which incumbents hold office (war/peace, austerity/ prosperity). The discovery that there are correlations in the rankings of prime ministers who held office concurrently and governed in similar international circumstances would prima facie suggest that the fate of those leaderships was significantly bound by their timing, as Laing and McCaffrie (Chapter 4) would claim. By juxtaposing analyses of rankings of prime ministers in four countriessomething that has not been done previously-Part III of this volume opens up such additional avenues of inquiry.

\section{This Volume}

In the three parts that follow, each of the three core areas in prime-ministerial studies singled out above will be tackled. Part I on prime-ministerial power contains theoretical as well as explorative treatments of hitherto neglected or underdeveloped ways of conceptualizing the nature of prime-ministerial power to perform public leadership. Parts II and III are resolutely empirical in scope, with the grouping of thematically focused country case studies allowing readers to compare and contrast developments within and across the four jurisdictions studied. Throughout this enterprise we have limited the scope of our efforts to the Westminster world, so as to control for some key factors that we know provide for significant variation in the nature of the prime-ministerial role-in particular the electoral system (with 'pure' Westminster majoritarian systems producing single-party government or single-party dominated governments, as opposed to the multi-party coalitions typically associated with proportional representation), and the monistic nature of the relation between cabinet and parliament (with cabinet members being full-scale MPs and thus party elites rather than externally recruited technocrats). Each section of the volume opens with an editorial introduction describing the section's aim and approach, prefacing the individual chapters and providing pointers for the reader to keep in mind when combing through their contents. The volume is concluded by a programmatic essay by R. A. W. Rhodes, an inveterate and influential innovator in the field of executive leadership studies. He once more challenges colleagues to broaden our intellectual programme (from 'prime ministerial' to 'court politics') and (p.22) reorient our methodology (from comparative 
institutionalism to political anthropology). Indeed, for Rhodes, the study of court politics is a means to further advance the agenda we pursue in this volume.

References

Bibliography references:

Aarts, K., Blais, A. and Schmitt, H. eds. 2011. Political Leaders and Democratic Elections. Oxford: Oxford University Press.

Abjorensen, N. 1992. Australia's top 10 PMs. Canberra Times, 5 December.

Abse, L. 2003. Tony Blair: The Man Behind the Smile. London: Robson Books.

Allan, G. 2003. The Last Prime Minister: Being Honest About the UK Presidency. London: Imprint Academic.

Anson, S. 1992. Hawke: An Emotional Life. Ringwood: McPhee Gribble.

Bailey, T. A. 1966. Presidential Greatness: The Image and the Man from George Washington to the Present. New York: Appleton-Century.

Bakvis, H. 2001. Prime minister and cabinet in Canada: An autocracy in need of reform. Journal of Canadian Studies, 35: 60-79.

Ballard, E. J. and Suedfeld, P. 1988. Performance ratings of Canadian prime ministers: Individual and situational factors. Political Psychology, 9: 291-302.

Barber, J. D. 1972. The Presidential Character: Predicting Performance in the White House. Englewood Cliffs: Prentice Hall

Baring, A. and Schöllgen, G. 2002. Kanzler, Krisen, Koalitionen: Von Konrad Adenauer bis Angela Merkel. Berlin: Siedler.

Bean, C. and Mughan, A. 1989. Leadership effects in parliamentary elections in Australia and Britain. American Political Science Review, 83: 1165-79.

Bennister, M. 2007. Tony Blair and John Howard: Comparative predominance and institution stretch in the UK and Australia. The British Journal of Politics and International Relations, 9: 327-45.

Bennister, M. 2012. Prime Ministers in Power: Blair and Howard Compared. Basingstoke: Palgrave.

Bevir, M. and Rhodes, R. A. W. 2006. Prime ministers, presidentialism and Westminster smokescreens. Political Studies, 54: 671-90.

Bevir, M. and Rhodes, R. A. W. 2008. The differentiated polity as narrative. The British Journal of Politics \& International Relations, 10: 729-34. 
Blair, T. 2010. A Journey: My Political Life. New York: Knopf.

Blick, A. and Jones, G. 2010. Premiership. London: Imprint Academic.

Blondel, J. and Muller-Rommel, F. eds. 1994. Governing Together. London: Macmillan.

Blondel, J. and Thiébault, J. 2009. Political Leadership, Parties and Citizens: The Personalisation of Leadership. London: Routledge

Boin, A., 't Hart, P. and Van Esch, F. 2012. Political leadership in times of crisis: Comparing leader responses to financial turbulence. pp. 119-41 in Comparative Political Leadership, ed. L. Helms. Basingstoke: Palgrave.

Bose, M. and Landis, M. eds. 2003. Making the Grade: The Uses and Abuses of Presidential Ratings. New York: Nova Science Publishers.

(p.23) Brett, J. 1993. Robert Menzies' Forgotten People. Sydney: Sun Australia.

Brett, J. ed. 1997. Political Lives. Sydney: Allen \& Unwin.

Brett, J. and Moran, A. 2006. Ordinary People's Politics: Australians Talk About Life, Politics and the Future of Their Country. Melbourne: Pluto Press.

Butler, D., Adonis, A. and Travers, T. 1994. Failure in British Government: The Politics of the Poll Tax. Oxford: Oxford University Press.

Cowen, T. 2000. What Price Fame? Cambridge: Harvard University Press.

Curran, J. 2004. The Power of Speech: Australian Prime Ministers Defining the National Image. Melbourne: Melbourne University Press.

Dalton, R. J. and Wattenberg, M. P. eds. 2000. Parties Without Partisans: Political Change in Advanced Industrial Democracies. Oxford: Oxford University Press.

Davis, G. 2012. Leader of the Gang: How Political Parties Choose Numero Uno. Published as an eSingle at www.griffithreview.com

De Landtsheer, C. 2004. Political Impression Management in Flanders and in The Netherlands. Leuven: Acco.

Doerner, A. 2001. Politainment: Politik und Unterhaltungskultur in Deutschland. Frankfurt: Suhrkamp.

Donaldson, G. 1999. The Prime Ministers of Canada. Toronto: Doubleday.

Dowding, K. 2012. The prime ministerialisation of the British prime minister. Parliamentary Affairs, published online 6 April at http://pa.oxfordjournals.org/ content/early/2012/04/12/pa.gss007 
Dyson, S. B. 2006. Personality and foreign policy: Tony Blair's Iraq decisions, Foreign Policy Analysis, 2(3): 289-306.

Dyson, S. B. 2007. Alliances, domestic politics, and leader psychology: Why did Britain stay out of Vietnam and go into Iraq? Political Psychology, 28: 647-66.

Dyson, S. B. 2009. The Blair Identity: Leadership and Foreign Policy.

Manchester: Manchester University Press.

Eland, I. 2009. Recarving Rushmore: Ranking the Presidents on Peace, Prosperity and Liberty. Oakland: California Independent Institute.

Elgie, R. 1995. Political Leadership in Liberal Democracies. Houndmills: Macmillan.

Ellis, R. and Wildavsky, A. 1989. Dilemmas of Presidential Leadership From Washington Through Lincoln. New Brunswick: Transaction.

Esberey, J. E. 1980. Knight of the Holy Spirit: A Study of William Lyon Mackenzie King. Toronto: University of Toronto Press.

Faber, C. and Faber, R. 2000. The American Presidents Ranked by Performance. Jefferson: McFarland \& Co.

Feit, E. ed. 1978. Governments and Leaders: An Approach to Comparative Politics. Boston: Houghton Mifflin.

Feldman, O. and Valenty, L. O. 2001. Profiling Political Leaders: Cross-Cultural Studies of Personality and Behavior. Westport: Praeger.

Foley, M. 2000. The British Presidency: Tony Blair and the Politics of Public Leadership. Manchester: Manchester University Press.

Foley, M. 2004. Presidential attribution as an agency of prime ministerial critique in a parliamentary democracy: The case of Tony Blair. The British Journal of Politics and International Relations, 6: 292-311.

(p.24) Gaffney, J. 1991. The Language of Political Leadership in Contemporary Britain, Basingstoke: Macmillan.

Granatstein, J. L. and Hillmer, N. 1999. Prime Ministers: Ranking Canada's Leaders. Toronto: Harper Collins.

Greenstein, F. I. 1982. The Hidden-Hand Presidency: Eisenhower as Leader. New York: Basic Books.

Greenstein, F. I. 2000. The qualities of effective presidents: An overview from FDR to Bill Clinton. Presidential Studies Quarterly, 30: 178-85. 
Hajer, M. A. 2009. Authoritative Governance. Oxford: Oxford University Press.

Hargrove, E. C. and Owens, J. E. 2003. Leadership in Context. Lanham: Rowman and Littlefield.

Hart, J. 1992. An American President? A Comparative Perspective. pp. 183-201 in Menzies to Keating: The Development of the Australian Prime Ministership, ed. P. Weller. Melbourne: Melbourne University Press.

Heffernan, R. 2005a. Exploring (and explaining) the British prime minister. The British Journal of Politics and International Relations, 7: 605-20.

Heffernan, R. 2005b. Why the prime minister cannot be a president: Comparing institutional imperatives in Britain and America. Parliamentary Affairs, 58: 5370 .

Helms, L. 2002. Chief executives and their parties. German Politics, 11: 146-64.

Helms, L. 2005. Presidents, Prime Ministers, and Chancellors: Executive Leadership in Western Democracies. Basingstoke: Palgrave.

Helms, L. 2008. Governing in the media age: The impact of the mass media on executive leadership in contemporary democracies. Government and Opposition, 43: 26-54.

Helms, L. ed. 2012. Comparative Political Leadership. Basingstoke: Palgrave.

Hennessy, P. 2000. The Prime Minister: The Office and its Holders Since 1945. Harmondsworth: Penguin Books.

Hermann, M. G. 1980. Explaining foreign policy behavior using personal characteristics of political leaders. International Studies Quarterly, 24: 7-46.

Hermann, M. G. 1984. Personality and foreign policy decision making: A study of 53 heads of government. pp. 53-80 in Foreign Policy Decision-Making, ed. D. A. Sylvan and S. Chan. New York: Praeger.

Hirst, J. 2010. Looking for Australia: Historical Essays. Melbourne: Black Inc. Janis, I. L. 1989. Crucial Decisions. New York: Free Press.

Johansson, J. 2009. The Politics of Possibility: Leadership in Changing Times. Wellington: Dunmore.

Jones, G. W. 1964. The prime minister's power. Parliamentary Affairs, 18: 16785.

Jones, G. W. ed. 1991. West European Prime Ministers. London: Frank Cass. 
Kaarbo, J. 1997. Prime ministerial leadership styles in foreign policy decisionmaking. Political Psychology, 18: 553-81.

Kaarbo, J. and Hermann, M. G. 1998. Leadership styles of prime ministers. Leadership Quarterly, 9: 243-63.

Kane, J. and Patapan, H. 2012. The Democratic Leader: How Democracy Defines, Empowers and Limits its Leaders. Oxford: Oxford University Press.

Katz, R. S. and Mair, P. 1995. Changing models of party organization and party democracy: The emergence of the cartel party. Party Politics, 1: 5-31.

(p.25) Kavanagh, D. and Seldon, A. 1999. The Powers Behind the Prime Minister: The Hidden Influence of Number Ten. London: HarperCollins.

Kellerman, B. 2004. Bad Leadership. Cambridge: Harvard Business School Press.

Kelly, P. 2009. The March of Patriots: The Struggle for Modern Australia.

Melbourne: Melbourne University Press.

King, A. 1994. Chief executives in Western Europe. pp. 150-63 in Developing Democracy: Comparative Research in Honour of J.F.P. Blondel, ed. I. Budge and D. McKay. London: Sage.

King, A. ed. 2002. Leaders' Personalities and the Outcomes of Democratic Elections. Oxford: Oxford University Press.

Laing, M. and 't Hart, P. 2011. Seeking and keeping the hot seat: A comparative analysis of party leader successions. pp. 111-33 in How Power Changes Hands: Transition and Succession in Government, ed. P. 't Hart and J. Uhr. Basingstoke: Palgrave.

Langford, P. 2006. Prime ministers and parliaments. Parliamentary History, 25: 382-94.

Langguth, G. 2009. Kohl, Schröder, Merkel: Machtmenschen. München: DTV Verlag.

LeDuc, L. 2001. Democratizing party leadership selection. Party Politics, 7: 32341.

Lijphart, A. 1999. Patterns of Democracy. New Haven: Yale University Press.

Lipman-Blumen, J. 2004. The Allure of Toxic Leaders. New York: Oxford University Press.

Lotz, J. 1987. Prime Ministers of Canada. London: Bison Books. 
McAllister, I. 2003. Prime ministers, opposition leaders and government popularity in Australia. Australian Journal of Political Science, 38: 259-77.

McAllister, I. 2007. Personalisation of politics. pp. 571-88 in The Oxford Handbook of Political Behaviour, ed. R. J. Dalton. Oxford: Oxford University Press.

McAllister, I. 2011. The Australian Voter: 50 Years of Change. Sydney: UNSW Press.

McAllister I. and Bean C. 2006. Leaders, the economy or Iraq? Explaining voting in the 2004 Australian election. Australian Journal of Politics and History, 52(4): 604-20.

MacDonald, L. I. 2003. The best prime ministers of the last 50 Years-Pearson, by a landslide. Policy Options, June/July: 8-12.

Maranell, G. M. 1970. The evaluation of presidents: An extension of the Schlesinger polls. The Journal of American History, 57: 104-13.

Marr, D. 2010. Power Trip: The Political Journey of Kevin Rudd. Melbourne: Black Inc.

Marsh, I. ed. 2006. Political Parties in Transition? Annandale: Federation Press.

März, P. 2002. An der Spitze der Macht: Kanzlerschaften und Wettbewerber in Deutschland. München: Olzog Verlag.

Masters, A. and 't Hart, P. 2012. Prime ministerial rhetoric and recession politics: Meaning making in economic crisis management. Public Administration, 90(3): 759-80.

Meacher, M. 2010. Chilcot's unfinished business. Guardian, 3 April. At: http:// www.guardian.co.uk/commentisfree/2010/apr/03/chilcot-inquiry-iraq-power

Meyer, T. 2001. Media Democracy. Cambridge: Polity Press.

Murray, R. K. and Blessing, T. H. 1994. Greatness in the White House: Rating the Presidents. University Park: Pennsylvania State University Press.

Nye, J. 2008. The Powers to Lead. New York: Oxford University Press.

(p.26) O'Malley, E. 2007. The power of prime ministers: The result of an expert survey. International Political Science Review, 28: 1-22.

Oborne, P. 2007. The Triumph of the Political Class. London: Simon \& Schuster.

Pakulski, J. and Körösényi, A. 2012. Toward Leader Democracy. London: Anthem Press. 
Pal, L. and Taras, D. eds. 1988. Prime Ministers and Premiers: Political Leadership and Public Policy in Canada. Scarborough: Prentice-Hall.

Pfiffner, J. P. 2003. Ranking the President: Continuity and Volatility. pp. 27-42 in The Uses and Abuses of Presidential Ratings, ed. M. Bose and M. Landis. New York: Nova Science.

Pious, R. M. 2003. Reflections of a presidency rater. White House Studies, 3: 6370.

Pious, R. M. 2008. Why Presidents Fail. Lanham: Rowman \& Littlefield.

Poguntke, T. and Webb, P. D. eds. 2005. The Presidentialization of Politics: A Comparative Study of Modern Democracies. Oxford: Oxford University Press.

Post, J. ed. 2003. The Psychological Assessment of Political Leaders. Ann Arbor: University of Michigan Press.

Preston, T. 2001. The President and his Inner Circle. Princeton: Princeton University Press.

Rawnsley, A. 2010. The End of the Party. London: Viking.

Rhodes, R. A. W. 2007. Blair and governance. pp. 95-116 in Public Governance and Leadership: Political and Managerial Problems in Making Public Governance Changes the Driver for Re-constituting Leadership, ed. J. Dixon and R. Koch. Wiesbaden: Deutscher Universitats-Verlag.

Rhodes, R. A. W. 2011. Everyday Life in British Government. Oxford: Oxford University Press.

Rhodes, R. A. W. and Dunleavy, P. eds. 1995. Prime Minister, Cabinet and Core Executive. London: Macmillan.

Rhodes, R. A. W., Wanna, J. and Weller, P. 2009. Comparing Westminster. Oxford: Oxford University Press.

R. A. W. Rhodes, 't Hart, P. and Noordegraaf M. eds. 2007. Observing Government Elites: Up Close and Personal. Basingstoke: Palgrave.

Richardson, G. 1994. Whatever it Takes. Sydney: Bantam Books.

Rose, R. 2001. The Prime Minister in a Shrinking World. Oxford: Polity Press.

Rothstein, B. 2011. The Quality of Government: Corruption, Social Trust and Inequality in International Perspective. Chicago: University of Chicago Press.

Ruin O. 1986. Tage Erlander: A Political Biography. Pittsburgh: Pittsburgh University Press. 
Ruin, O. 2007. Statsministern: Från Tage Erlander Till Göran Persson.

Stockholm: Gidlund.

Ryan, M. ed. 1995. Advancing Australia: The Speeches of Paul Keating. Sydney: Big Picture Publications.

Sanders, K., Bale, T. and Canel, M. J. 1999. Managing sleaze: Prime ministers and news management in Conservative Great Britain and Socialist Spain. European Journal of Communication, 14: 461-86.

Savoie, D. J. 2003. Breaking the Bargain: Public Servants, Ministers, and Parliament, Toronto: University of Toronto Press.

(p.27) Schlesinger, A. M. 1997. Rating the presidents: Washington to Clinton. Political Science Quarterly, 112: 179-90.

Seymour-Ure, C. 2003. Prime Ministers and the Media. Oxford: Blackwell.

Sheppard, S. 1998. Ranking New Zealand's prime ministers. Political Science, 50: 72-89.

Simonton, D. K. 1987. Why Presidents Succeed: A Political Psychology of Leadership. New Haven: Yale University Press.

Skidmore, M. J. 2001. Ranking and evaluating presidents: The case of Theodore Roosevelt. White House Studies, 1: 495-505.

Skidmore, M. J. 2004. Presidential Performance: A Comprehensive Review. Jefferson: McFarland \& Co.

Smith, M. 1999. The Core Executive in Britain. Basingstoke: Palgrave.

Spencer, G. 2003. Pushing for peace: The Irish government, television news and the Northern Ireland peace process. European Journal of Communication, 18: 55-80.

't Hart, P. 1994. Groupthink in Government. Baltimore: Johns Hopkins University Press.

'T Hart, P. (2011) Evaluating public leadership: Towards an assessment framework. Public Money and Management, 31(5): 323-30.

't Hart, P. and Tindall, K. eds. 2009. Framing the Global Meltdown: Crisis Rhetoric and the Politics of Recessions. Canberra: ANU E Press.

't Hart, P. and Uhr, J. eds. 2008. Public Leadership: Perspectives and Practices. Canberra: ANU E Press. 
Taranto, J. and Leo, L. eds. 2004. Presidential Leadership: Rating the Best and Worst in the White House. New York: Wall Street Journal Books.

Theakston, K. 2002. Political skills and context in prime ministerial leadership in Britain. Politics \& Policy, 30: 283-323.

Theakston, K. and Gill, M. 2006. Rating 20th-century British prime ministers. The British Journal of Politics and International Relations, 8: 193-213.

Tiernan, A. 2007. Power Without Responsibility. Sydney: University of New South Wales Press.

Toye, R. 2011. The rhetorical premiership: A new perspective on prime ministerial power since 1945. Parliamentary History, 30: 175-92.

Uhr, J. 2002. Political leadership and rhetoric. pp. 261-94 in Australia Reshaped: 200 Years of Institutional Transformation, ed. H.G. Brennan and F.G. Castles. Melbourne: Cambridge University Press.

Uhr, J. 2003. Just rhetoric? Exploring the language of leadership. pp. 123-44 in Management, Organisation and Ethics in the Public Sector, ed. P. Bishop, C. Connors and C. Sampford. London: Routledge.

Verbeek, B. 2003. Decision Making in Great Britain During the Suez Crisis. Aldershot: Ashgate.

Walter, J. 1980. The Leader: A Political Biography of Gough Whitlam. St Lucia: University of Queensland Press.

Walter, J. 1981. Language and habits of thought: biographical notes on E. G. Whitlam. Biography, 4(1): 17-44.

Walter, J. 1986. The Ministers' Minders: Personal Advisers in National Government. Melbourne: Oxford University Press.

(p.28) Walter, J. 2006. Ministers, minders and public servants: Changing parameters of responsibility in Australia. Australian Journal of Public Administration, 65: 22-7.

Walter, J. 2008. Is there a command culture in politics? The Canberra case. pp. 189-201 in Public Leadership: Perspectives and Practices, ed. P. 't Hart and J. Uhr. Canberra: ANU E Press.

Walter, J. 2009. 'My heart bleeds': Personalities, ideas and the drama of fusion. pp. 188-224 in Confusion: The Making of the Australian Two-Party System, ed. P. Strangio and N. Dyrenfurth. Melbourne: Melbourne University Press. 
Walter, J. and Strangio, P. 2007. No, Prime Minister: Reclaiming Politics from Leaders. Sydney: UNSW Press.

Weller, P. 1985. First Among Equals: Prime Ministers in Westminster Systems. Sydney: Allen \& Unwin.

Weller, P. 1991. Prime ministers, political leadership and cabinet government. Australian Journal of Public Administration, 50(2): 131-44.

Weller, P. ed. 1992. Menzies to Keating: The Development of the Australian Prime Ministership. Melbourne: Melbourne University Press.

Weller, P. 1994. Party rules and the dismissal of prime ministers. Parliamentary Affairs, 47: 133-43.

Weller, P. 2007. Cabinet Government in Australia, 1901-2006. Sydney: UNSW Press.

Weller, P., Bakvis, H. and Rhodes, R. A. W. eds. 1997. The Hollow Crown: Countervailing Trends in Core Executives. London: Macmillan.

Winter, D. G. 2005. Things I've learned about personality from studying political leaders at a distance. Journal of Personality, 7: 557-84.

\section{Access brought to you by:}

